\title{
PERILAKU PENCARIAN INFORMASI BEASISWA MAHASISWA FAKULTAS ILMU BUDAYA UNIVERSITAS DIPONEGORO MELALUI MEDIA ONLINE
}

\author{
Ary Kusumaning Putri ${ }^{\left.1^{*}\right) \text {, }}$ \\ Program Studi Ilmu Perpustakaan, Fakultas Ilmu Budaya, Universitas Diponegoro, \\ Email: ariputri80@gmail.com \\ Yanuar Yoga Prasetyawan ${ }^{1}$ \\ Program Studi Ilmu Perpustakaan, Fakultas Ilmu Budaya, Universitas Diponegoro, \\ Email: yanuaryoga@ live.undip.ac.id
}

Received : 18 July 2021

Revised : 15 September 2021 Accepted : 15 October 2021 DOI

\begin{abstract}
This study aimed to see how Information Seeking Behavior Scholarships Of Diponegoro University's Faculty Of Cultural Sciences Students Through Online Information Source This study used qualitative methods and purposive sampling technique in selecting informants. Data collection techniques in this study used interviews and in-depth interviews with 13 informants from the Faculty of Cultural Sciences, Diponegoro University. This study used thematic analysis as the method used to analyze data. The results of this study indicate that students of the Faculty of Humanities, Diponegoro University need scholarship opening information because there are several objectives that must be met, one of which is to meet financial needs. That factor encourages students to search for scholarship information by using various online media information sources such as the Google search engine, websites, instagram, facebook, twitter, line and whatsapp. Scholarship information search activities began by using information sources that have been used by students before or by asking questions to friends/relations and search activities ended by combining information, registering \& completing the required documents, providing scholarship information and reviewing the development of scholarship information. Information seeking activities experience several obstacles, namely students having difficulty in determining the right keywords, internet access constraints, related scholarships or the quality of scholarship information sources as well as the low credibility of scholarship information because providers of information sources do not filter and check the accuracy of information before it is publicized.

Keywords: scholarship information needs, information-seeking behavior, information source, online media.
\end{abstract}

\section{PENDAHULUAN}

Beasiswa merupakan salah satu kebutuhan informasi mahasiswa. Berdasarkan penelitian yang dilakukan oleh Oladokun dan Aina (2009) dan Chawinga dan Zozie (2016) dalam Thindwa et al., (2019) menemukan bahwa mahasiswa sangat membutuhkan informasi salah satunya mengenai informasi beasiswa. Universitas sebagai lembaga akademik tingkat pendidikan tinggi memberikan informasi beasiswa kepada mahasiswanya dalam rangka membantu upaya pemerintah menjalankan salah satu amanat Undang-Undang Dasar Negara Indonesia yaitu untuk mencerdaskan kehidupan bangsa untuk memperkecil 
angka kegagalan studi atau putus kuliah mahasiswa karena keterbatasan ekonomi (Mutijah, 2016). Hal ini dikarenakan banyak warga negara Indonesia tidak dapat melanjutkan pendidikan tinggi, dikarenakan banyak masyarakat Indonesia tidak sanggup melanjutkan pendidikan terkendala oleh biaya pendidikan atau biaya kuliah yang mahal (Utomo, 2011). Tingginya biaya kuliah dan minimnya biaya karena keterbatasan ekonomi juga menyebabkan salah satu alasan mahasiswa mengajukan cuti kuliah atau bahkan dropout (Rohmawati et al., 2015). Menurut Tarwanto, Watonah, Mudzakir dan Sutrisno dalam Mutijah, (2016) keadaan ekonomi orang tua merupakan salah satu penyebab yang dapat mempengaruhi prestasi akademik dan belajar mahasiswa. Keterbatasan keadaan ekonomi orang tua dapat menyebabkan kecemasan dan stress yang dirasakan oleh mahasiswa. Menurut Ross, Niebling, \& Heckert, (2008) dalam Musabiq \& Karimah, (2018) intrapersonal adalah stressor yang berasal dari dalam diri individu itu sendiri, misalnya kesulitan keuangan. Menurut Bressert (2016) dalam Musabiq \& Karimah, (2018) menunjukan bahwa stress mengakibatkan dampak yang digolongkan kedalam empat aspek diantaranya kognitif, emosi, fisik dan perilaku.

Universitas Diponegoro merupakan lembaga pendidikan tinggi yang memberikan atau menyediakan informasi beasiswa dari beberapa instansi kepada mahasiswanya. Hal ini dikarenakan beasiswa merupakan salah satu kebutuhan informasi mahasiswa. Mahasiswa melakukan kegiatan pencarian informasi beasiswa dikarenakan adanya kebutuhan informasi beasiswa yang harus dipenuhi. Menutut David Ellis dalam Amrullah et al., (2019) mengemukakan bahwa perilaku pencarian infomasi merupakan pola kegiatan tahapan atau langkah keseluruhan proses pencarian informasi yang berkaitan langsung dengan pengambilan informasi yang diperoleh dari sistem atau sumber informasi. Menurut Weber et al., (2019) media online saat ini sangat penting karena sebagai sarana mahasiswa untuk memperoleh atau mencari informasi karena kemudahan dalam mengaksesnya. Menurut Nihayati \& Laksmi, (2020) pencarian informasi tidak semua serta merta mulus dan sama bagi setiap individu. Proses ini menemui berbagai hambatan, baik dari faktor personal seperti faktor psikologis maupun faktor eksternal, seperti keterbatasan akses informasi dan keadaan lingkungan (Susilo, 2018). Peneliti menggunakan subjek penelitian Mahasiswa Fakultas Ilmu Budaya Universitas Diponegoro dikarenakan Mahasiswa Fakultas Ilmu Budaya Universitas Diponegoro banyak yang membutuhkan dan mengikuti atau mendapatkan beasiswa. Hal tersebut berdasarkan data Kemahasiswaan Fakultas Ilmu Budaya Universitas Diponegoro, terdapat 100 penerima beasiswa PPA pada tahun 2019 
(fib.undip.ac.id). Selain itu berdasarkan database beasiswa tahun 2020 Mahasiswa Fakultas Ilmu Budaya Universitas Diponegoro telah mendapatkan berbagai macam beasiswa diantaranya beasiswa Pertamina Foundation Sobat Bumi, Tanoto Foundation, Bright Scholarship, Paragon Scholarship, Unggulan Kemendikbud dan masih banyak lainya.

Penelitian sejenis sebelumnya yang berjudul "The impact of Korea's National Scholarship program on college students' academic achievement" oleh yang ditulis Yi, (2014). Penelitian ini bertujuan untuk mengetahui dampak program Beasiswa Nasional Korea kepada mahasiswa berpenghasilan rendah dan menengah terhadap hasil IPK. Hasil penelitian menunjukan bahwa pemberian beasiswa yang menghubungkan bantuan keuangan dengan prestasi akademik dapat meningkatkan hasil akademik. Namun hal tersebut tergantung pada jumlah bantuan beasiswa, apabila bantuan biaya tidak besar maka efek peningkatan prestasi akademik tidak begitu berpengaruh dan sebaliknya apabila bantuan beasiswa cukup tinggi maka dapat berpengaruh terhadap peningkatan prestasi akademik mahasiswa.

Berdasarkan penelitian sebelumnya yang ditulis Yi, (2014) menunjukan bahwa penelitian mengenai beasiswa lebih banyak mengkaji mengenai dampak atau pengaruh beasiswa terhadap hasil yang berhubungan dengan akademik mahasiswa dan belum pernah atau belum adanya penelitian yang mengkaji beasiswa dengan menggunakan sudut pandang atau kacamata penelitian mengenai perilaku pencarian informasi atau bagaimana seseorang mencari informasi mengenai beasiswa. Maka dalam penelitian ini, peneliti tertarik membahas mengenai perilaku pencarian informasi beasiswa melalui media online untuk mengisi celah atau ruang kosong yang belum dilakukan oleh penelitian sebelumnya. Sehingga penelitian ini akan berbeda dan menjadi keterbaruan dari penelitian-penelitian sejenis sebelumnya yang telah dilakukan.

Berdasarkan permasalahan dan latar belakang penelitian, maka peneliti tertarik untuk melakukan penelitian mengenai "Perilaku Pencarian Informasi Beasiswa Mahasiswa Fakultas Ilmu Budaya Universitas Diponegoro melalui Media Online". Penelitian ini memiliki rumusan masalah dan tujuan untuk mengetahui perilaku pencarian informasi beasiswa Mahasiswa Fakultas Ilmu Budaya Universitas Diponegoro melalui media online. Penelitian ini diharapkan dapat memperluas khazanah peneliltian bidang ilmu perpustakaan dan informasi dan dapat menjadi rujukan dalam pengembangan topik penelitian yang berhubungan dengan perilaku pencarian informasi beasiswa melalui media online. Bagi 
penyedia informasi beasiswa, penelitian ini dapat menjadi bahan evaluasi untuk membantu meningkatkan sumber atau layanan informasi beasiswa yang baik seperti meningkatkan akses informasi beasiswa melalui sumber informasi media online yang digunakan bagi pengguna atau mahasiswa dalam mencari informasi beasiswa melalui media online.

\section{METODE}

Penelitian ini menggunakan metode penelitian kualitatif. Menurut Creswell (2008) dalam Semiawan (2010) metode penelitian kualitatif adalah suatu pendekatan atau penelusuran untuk mengeksplorasi dan memahami suatu gejala sentral secara deskriptif. Menurut Oun dan Bach (2014) dalam Helaluddin dan Wijaya (2019) metode penelitian kualitatif yaitu metode untuk menguji dan menjawab pertanyaan tentang apa, kapan, dimana, bagaimana, dan mengapa seseorang bertindak atau berperilaku dengan cara-cara tertentu pada permasalahan yang spesifik. Sehingga metode kualitatif merupakan metode yang sesuai dengan tujuan penelitian ini yaitu untuk mengetahui dan mengeksplorasi perilaku pencarian informasi Mahasiswa Fakultas Ilmu Budaya Universitas Diponegoro dalam mencari beasiswa melalui media online yang disajikan secara deskriptif.

Teknik pengambilan data dalam penelitian ini mengguanakan teknik wawancara semiterstruktur dan dokumentasi. Menurut Sugiyono (2007) dalam Yulma, N. L., \& Herianingrum, S. (2016) wawancara semiterstruktur yaitu teknik wawancara saat mengajukan pertanyaan kepada informan lebih bebas, karena informan dimintai ide atau pendapat mengenai fenomena yang dialami terkait dengan penelitian. Peneliti mengajukan pertanyaan terkait perilaku pencarian informasi beasiswa melalui media online secara fleksibel dan lebih bebas namun sesuai dengan tujuan penelitian. Menurut Sugiyono (2014) dalam Ariotejo (2019) dokumentasi adalah suatu cara yang digunakan untuk memperoleh data dan informasi dalam bentuk dokumen, buku, arsip, tulisan angka dan gambar yang berupa keterangan serta laporan yang dapat mendukung penelitian. Peneliti menggunakan teknik dokumentasi untuk mengumpulkan data kemudian ditelaah. Dokumentasi yang digunakan dalam penelitian ini meliputi website dan postingan media sosial yang memuat informasi beasiswa.

Dalam penelitian ini, peneliti menggunakan teknik purposive sampling. Menurut Sugiyono (2012) dalam Devega (2019) teknik proposive sampling yaitu peneliti menggunakan pertimbangan kriteria tertentu yang sesuai dengan tujuan penelitian dalam melakukan pengambilan sampel. Kriteria informan yang peneliti gunakan dalam penelitian ini yaitu Mahasiswa aktif Fakultas Ilmu Budaya Universitas Diponegoro tahun angkatan 
2018 dan 2019 yang pernah atau sedang mencari informasi beasiswa melalui media online. Berdasarkan kriteria tersebut peneliti mendapatkan dan melakukan wawancara kepada 13 informan yang dilakukan dengan cara peneliti membuat dan membagikan pamflet atau selebaran dalam bentuk digital melalui media sosial dan grup chat Mahasiswa Fakultas Ilmu Budaya Universitas Diponegoro angkatan 2018 dan 2019 yang didalamnya tercantum kriteria informan dan reward. Peneliti mencantumkan reward pada pamflet atau selebaran dengan tujuan untuk menarik informan yang memenuhi kriteria agar bersedia melakukan wawancara. Wawancara dilakukan secara mendalam dengan menggunakan media elektronik melalui sambungan telepon. Pertanyaan wawancara yang diajukan kepada informan dalam penelitian ini terkait perilaku pencarian informasi beasiswa melalui media online. Peneliti melakukan wawancara kepada 13 informan dikarenakan data yang peneliti dapatkan sudah jenuh. Menurut Linclon dan Guba (1985) dalam Sjach, B. (2009) pengambilan sampel dihentikan ketika tidak ada informasi baru yang datang dari unit sampel yang baru atau data sudah jenuh.

Dalam penelitian ini data dianalisis dengan menggunakan thematic analysis. Thematic analysis adalah analisis data yang dilakukan dengan cara mengidentifikasi pola atau menemukan tema terkait dengan data penelitian (Braun \& Clarke, 2006). Dalam Heriyanto (2018) terdapat 3 tahapan dalam melakukan thematic analysis yaitu terdiri dari (1) memahami data, (2)menyusun kode, (3)mencari tema. Dalam penelitian ini peneliti memahami data dengan cara membaca transkip wawancara secara berulang dan mendengarkan kembali rekaman wawancara. Selanjutnya peneliti membuat kode pada transkip wawancara yang relevan yang mengandung makna yang berkaitan dengan perilaku pencarian informasi beasiswa melalui media online dan mengelompokan kode yang memiliki makna yang sama menjadi satu grup atau kelompok. Dalam penelitian ini didapatkan 31 kode. Selanjutnya peneliti menentukan tema dari masing-masing kelompok kode, sehingga didapat 4 tema yang sesuai dengan rumusan masalah dan tujuan penelitian yaitu untuk mengetahui bagaimana perilaku pencarian informasi Mahasiswa Fakultas Ilmu Budaya Universitas Diponegoro dalam mencari beasiswa melalui media onlline. Penelitian ini dilakukan di Fakultas Ilmu Budaya Universitas Diponegoro dengan lama waktu penelitian selama 8 bulan. Peneliti menggunakan pendapat Lincoln dan Guba (1985) untuk menjaga kualitas penelitian (maintaining quality) yang diuji dengan credibility, transferability, dependability dan confirmability. 


\section{HASIL DAN PEMBAHASAN}

Penelitian tentang perilaku pencarian informasi merupakan serangkaian penelitian mengenai kegiatan atau cara yang dilakukan untuk mencari informasi yang diperoleh dari sistem atau dengan menggunakan sumber informasi sebagai upaya untuk memenuhi kebutuhan informasi. Namun, setiap individu dalam melakukan kegiatan atau proses pencarian informasi terdapat hambatan atau tidak semua dapat berjalan dengan lancar. Hambatan yang dialami individu dalam mencari informasi dapat dijadikan sebagai bahaan evausi untuk membantu penyedia sumber informasi merancang sistem layanan atau sumber informasi yang baik seperti meningkatkan akses informasi untuk pengguna. Oleh karena itu dalam penelitian perilaku pencarian informasi beasiswa Mahasiswa Fakultas Ilmu Budaya Universitas melalui media online memunculkan empat kategori berikut:

\section{Kebutuhan Informasi Beasiswa Mahasiswa Fakultas Ilmu Budaya Universitas Diponegoro}

Mahasiswa Fakultas Ilmu Budaya Universitas Diponegoro membutuhkan informasi beasiswa yang menyebabkan mahasiswa melakukan kegiatan pencarian informasi beasiswa melalui media online. Kebutuhan informasi yang dirasakan individu dapat mendorong melakukan kegiatan pencarian informasi yang disebabkan karena adanya tujuan tertentu. Mahasiswa Fakultas Ilmu Budaya Universitas Diponegoro membutuhkan dan mencari informasi beasiswa karena mempunyai tujuan diantaranya untuk memenuhi kebutuhan finansial dan mengembangkan soft skill yang didapatkan dari program pelatihan yang diberikan oleh penyelenggara beasiswa. Selain itu tujuan mahasiswa membutuhkan dan mencari informasi beasiswa juga dikarenakan ingin menambah pengalaman baru serta teman atau relasi baru.

Mahasiswa Fakultas Ilmu Budaya Universitas Diponegoro membutuhkan informasi terkait beasiswa seperti informasi mengenai persyaratan, deadline atau timeline serta manfaat yang diberikan oleh beasiswa. Ketiga informasi tersebut merupakan informasi penting yang dicari oleh mahasiswa. Selain ketiga informasi tersebut mahasiswa juga membutuhkan informasi lain terkait beasiswa yaitu seperti informasi mengenai tahapan sistem seleksi beasiswa, tata cara atau mekanisme pendaftaran dan pemberkasan, deskripsi beasiswa, penyelenggara beasiswa, hal yang dilakukan mahasiswa setelah mendapat beasiswa, serta alumni penerima beasiswa.

Mahasiswa Fakultas Ilmu Budaya Universitas Diponegoro memiliki kriteria tersendiri dalam memilih atau mencari beasiswa. Kriteria beasiswa yang dibutuhkan atau dicari Mahasiswa Fakultas Ilmu Budaya Universitas Diponegoro yaitu mahasiswa memilih 
beasiswa dengan kredibilitas informasi beasiswa dapat dipercaya dan memilih beasiswa yang memiliki banyak pendaftar. Selain itu juga mahasiswa memilih beasiswa yang memiliki tenggang waktu yang cukup lama dengan deadline pendaftaran sehingga mahasiswa masih mempunyai waktu untuk mempersiapkan pendaftaran. Namun, mahasiswa memiliki kriteria yang paling utam dalam memilih beasiswa yaitu dengan melihat persyaratan dan manfaat yang didapatkan sesuai dengan kebutuhan. Mahasiswa memilih manfaat yang didapat tidak hanya berupa uang tetapi juga memilih beasiswa yang terdapat pelatihan yang diberikan oleh pihak penyelenggara beasiswa.

Penelitian ini sejalan dengan penelitian sebelumnya yang ditulis oleh Suwanto (1997), menurut Belkin (1978) kebutuhan informasi dapat terjadi dikarenakan kurangnya tingkat pengetahuan mengenai topik atau situasi tertentu atau dapat dikatakan adanya kesenjangan yang dimiliki individu antara pengetahuan yang dibutuhkan dengan pengetahuan yang dimiliki untuk menyelesaikan masalah yang dihadapi. Kebutuhan informasi dapat dikatakan sebagai sesuatu informasi yang ingin diketahui oleh seseorang karena adanya kesenjangan informasi sehingga mendorong individu untuk melakukan kegiatan pencarian informasi sebagai suatu kemampuan atau usaha yang dilakukan untuk memenuhi informasi yang dibutuhkan. Mahasiswa Fakultas Ilmu Budaya Universitas Diponegoro membutuhkan informasi terkait beasiswa karena memiliki beberapa tujuan yang harus dipenuhi salah satu tujuanya yaitu mahasiswa ingin mengatasi masalah terkait finansial. Sehingga mendorong mahasiswa untuk melakukan atau mencari informasi beasiswa melalui media online sebagai suatu usaha agar kebutuhan informasi dan tujuan mahasiswa mencari informasi beasiswa dapat terpenuhi.

\section{Sumber Informasi yang Digunakan Mahasiswa Fakultas Ilmu Budaya Universitas Diponegoro dalam Mencari Informasi Beasiswa}

Mahasiswa Fakultas Ilmu Budaya Universitas Diponegoro dalam memenuhi kebutuhan informasi beasiswa menggunakan sumber informasi media online untuk mencari informasi beasiswa dikarenakan mahasiswa setiap hari tidak dapat terlepas dari gadget dan hampir setiap hari mahasiswa membuka atau mengakses informasi melalui media sosial karena dirasa lebih mudah. Ditambah lagi di masa pandemi seperti ini informasi yang saat ini mudah diakses atau diperoleh yaitu melalui media online karena pada saat ini hampir semua informasi tersaji secara online. Selain itu alasan Mahasiswa Fakultas Ilmu Budaya Universitas Diponegoro menggunakan media online dalam mencari informasi beasiswa 
karena media online mempunyai kelebihan diantaranya lebih cepat diakses sehingga lebih efisien waktu dan lebih mudah dicari atau lebih mudah mendapatkan informasi beasiswa yang sesuai dengan apa yang mahasiswa butuhkan karena informasi beasiswa yang ada di media online lebih banyak dan lengkap. Mencari informasi beasiswa melalui media online juga terdapat kekurangannya yaitu semua informasi yang terdapat di media online belum tentu benar, maka mahasiswa harus lebih teliti dan selektif dalam memilih informasi beasiswa atau sumber informasi beasiswa yang digunakan.

Terdapat beberapa jenis media online yang digunakan Mahasiswa Fakultas Ilmu Budaya Universitas Diponegoro dalam mencari informasi beasiswa melalui media online. Jenis media online yang digunakan diantaranya google website, instagram, facebook, twitter, grup chat lainnya seperti line atau whatsapp. Instagram merupakan media online yang paling sering digunakan mahasiswa dalam mencari informasi beasiswa karena instagram isi informasinya lebih ringkas, lebih menarik, to the point, lebih mudah karena terdapat hashtag serta hyperlink yang dapat menghubungkan mahasiswa ke website atau instagram resmi penyelenggara beasiswa. Mahasiswa dalam mencari informasi beasiswa juga melalui website, hal ini dikarenakan informasi yang terdapat di website lebih lengkap dan rinci. Mahasiswa dalam mencari informasi beasiswa melalui instagram menggunakan beberapa akun diantaranya akun instagram BEM seperti BEM FIB, BEM Undip, akun instagram himpunan program studi maupun akun instagram lainnya yang menyediakan informasi beasiswa seperti akun instagram info beasiswa dan sejenisnya. Terdapat kelebihan dari akun instagram BEM atau himpunan diantaranya informasinya lebih tersaring sesuai dengan pesyaratan mahasiswa, mudah dipahami, terdapat narahubung dan lebih valid. Namun akun BEM maupun himpunan program studi memiliki kekurangan diantaranya informasi beasiswanya jauh lebih sedikit, informasi beasiswa yang disebarkan jaraknya terlalu mendekati dengan deadline pendaftaran dan informasi beasiswa yang diberikan hanya sekilas. Sedangkan kelebihan akun instagram info beasiswa yaitu informasi beasiswa lebih banyak dan kekurangannya informasi beasiswanya kurang valid dan cakupan informasi beasiswanya terlalu luas.

Mahasiswa Fakultas Ilmu Budaya Universitas Diponegoro untuk menelusuri dan menggali informasi beasiswa lebih lanjut menggunakan akun instagram dan website resmi penyelenggara beasiswa. Informasi yang terdapat di website resmi penyelenggara beasiswa lebih lengkap namun kurang update jika dibandingkan dengan instagram resmi penyelenggara beasiswa. Sedangkan akun instagram resmi penyelenggara beasiswa informasinya lebih update, menarik dan terdapat remainder namun kekuranganya 
informasinya kurang lengkap dan lebih ringkas. Mahasiswa Fakultas Ilmu Budaya Universitas Diponegoro dalam mencari informasi beasiswa juga menggunakan atau memanfaatkan sarana sumber informasi beasiswa dari universitas yaitu berupa website BAK Undip dan fakultas berupa website FIB. Namun mahasiswa tidak selalu atau tidak semua memanfaatkan dan mengetahui website BAK Undip dan website FIB. Terdapat kelebihan dalam mencari informasi beasiswa melalui website BAK Undip dan website FIB diantaranya informasi beasiswa yang diberikan tidak hanya informasi pendaftaran namun juga informasi pengumuman dan perpanjangan, informasinya lebih lengkap, cepat, jelas, rinci dan lebih terverifikasi kebenaranya. Namun kekurangannya website BAK Undip dan website FIB informasi beasiswanya kurang variatif, terbatas, jarang membagikan informasi beasiswa dan tidak selalu membagikan atau memberikan informasi terbaru.

Mahasiswa juga mencari informasi beasiswa melalui teman atau relasi maupun alumni, dengan cara mahasiswa secara aktif bertanya mengenai informasi beasiswa maupun diberi rekomendasi tanpa harus bertanya. Sumber informasi teman atau relasi maupun alumni digunakan mahasiswa sebagai sumber informasi tambahan dan sumber informasi penghubung mahasiswa ke media online yang merupakan sumber informasi utama dalam mencari informasi beasiswa. Mahasiswa Fakultas Ilmu Budaya Universitas Diponegoro dalam mencari informasi beasiswa menggunakan lebih dari satu sumber dikarenakan untuk memastikan kredibilitas sumber dan untuk mengetahui informasi lebih lanjut atau informasi penting lainya agar mahasiswa mendapatkan lebih banyak informasi beasiswa secara lengkap dan jelas.

Penelitian ini sejalan dengan penelitian sebelumnya yang ditulis oleh Suwanto (1997), Chen dan Chermin mengemukakan bahwa dengan menggunakan berbagai sumber informasi dapat untuk mengatasi kesenjangan informasi manusia. Pada penelitian ini Mahasiswa Fakultas Ilmu Budaya Universitas Diponegoro menggunakan berbagai sumber informasi yang diperoleh dari media online seperti akun instagram BEM atau himpunan program studi, akun instagram dan website resmi atau media sosial resmi penyelenggara beasiswa, website BAK Undip, website FIB Undip dan sumber informasi lainya yang digunakan mahasiswa untuk mengatasi kesenjangan atau untuk memenuhi kebutuhan informasi mahasiswa terkait informasi beasiswa. Mahasiswa menggunakan sumber informasi untuk memperoleh atau mendapatkan informasi mengenai beasiswa. 


\section{Perilaku Pencarian Informasi Beasiswa Mahasiswa Fakultas Ilmu Budaya Universitas Diponegoro melalui Media Online}

Mahasiswa Fakultas Ilmu Budaya Universitas Diponegoro dalam mencari informasi beasiswa menggunakan sumber informasi media online terdapat tahapan atau langkah yang dilakukan dari awal pencarian hingga akhir sebelum akhirnya mahasiswa menemukan dan menggunakan informasi beasiswa sesuai dengan yang dibutuhkan. Mahasiswa Fakultas Ilmu Budaya Universitas Diponegoro dalam mencari informasi beasiswa menggunakan beberapa jenis media online diantaranya melalui instagram, search engine google, facebook, twitter, website BAK Undip, website FIB, dan melalui rekomendasi, bertanya atau share informasi beasiswa dari teman atau relasi melalui grup chat whatsapp atau line. Perilaku pencari informasi beasiswa melalui beberapa jenis media online tersebut kegiatan atau tahapanya memiliki pola yang sama.

Perilaku pencarian informasi Mahasiswa Fakultas Ilmu Budaya Universitas Diponegoro dalam mencari informasi beasiswa melalui media online dimulai dengan melakukan kegiatan starting yaitu dengan cara mencari informasi beasiswa dari sumber informasi yang pernah digunakan sebelumnya atau dengan bertanya kepada teman atau relasi. Selanjutnya mahasiswa melakukan kegiatan differentiating dengan cara membedakan atau memilah informasi beasiswa yang sesuai dengan persyaratan serta judul yang relevan dengan informasi yang dicari. Mahasiswa setelah memilah informasi beasiswa selanjutnya melakukan kegiatan chaining dengan cara mengikuti rangkain kutipan yang mengarahkan kepada sumber asli informasi yaitu website atau instagram resmi penyelenggara beasiswa. Lalu mahasiswa melakukan kegiatan browsing dengan cara memindai website resmi, instagram resmi maupun media sosial resmi penyelenggara beasiswa agar dapat mengetahui dan menemukan informasi yang dibutuhkan. Setelah itu mahasiswa melakukan kegiatan extracting denga cara menggali dan mengidentifikasi dengan selektif relevansi informasi beasiswa melalui website atau instagram resmi penyelenggara beasiswa dengan menyimpan atau mencatat informasi penting. Selanjutnya mahasiswa melakukan kegiatan monitoring dengan cara mem-follow akun instagram resmi penyelenggara beasiswa dengan tujuan untuk mengetahui dan memantau perkembanagan update informasi beasiswa. Lalu mahasiswa melakukan kegiatan verifying yaitu menilai dan memeriksa relevansi, keakuratan atau kebenaran serta kredibilitas informasi beasiswa yang didapat. Selanjutnya mahasiswa melakukan kegiatan ending dengan cara menggabungkan, mendaftar dengan mengumpulkan berkas persyaratan, berbagi informasi beasiswa serta memantau kembali perkembangan 
update informasi beasiswa. Selain itu sebelum mendaftar beberapa mahasiswa juga menanyakan kepada pihak penyelengggra, teman dan alumni apabila terdapat informasi yang kurang jelas atau kurang lengkap dengan tujuan untuk memastikan dan agar mendapatkan informasi tambahan yang tidak terdapat di media online dengan bertanya kepada alumni terkait pengalaman.

Penelitian ini sejalan dengan penelitian sebelumnya yang ditulis oleh Amrullah et al., (2019), David Ellis mengemukakan bahwa perilaku pencarian infomasi merupakan pola kegiatan tahapan atau langkah keseluruhan proses pencarian informasi yang berkaitan langsung dengan pengambilan informasi yang diperoleh dari sistem atau sumber informasi. David Ellis membagi perilaku pencarian informasi beasiswa kedalam 8 tahapan diantaranya starting, chaining, browsing, differentiating, monitoring, extracting, verifying dan ending. Model perilaku pencarian informasi Davis Ellis prosesnya tidak harus mengikuti semua langkah atau tahapan dalam urutan yang ketat dan tidak selalu terjadi dalam urutan tertentu dan dapat dimulai dalam urutan yang berbeda pada waktu yang berbeda dalam keseluruhan proses pencarian. Mahasiswa Fakultas Ilmu Budaya Universitas Diponegoro dalam mencari informasi beasiswa menggunakan sumber informasi media online terdapat tahapan atau langkah yang dilakukan dari awal pencarian hingga akhir diantaranya starting, differentiating, chaining, browsing, extracting, monitoring, verifying dan ending sebelum akhirnya mahasiswa menemukan dan menggunakan informasi beasiswa sesuai dengan yang dibutuhkan. Pada penelitian ini prosesnya terjadi pada urutan yang berbeda.

Pada penelitian ini tahap differentiating terjadi setelah tahap starting dan sebelum tahap chaining. Mahasiswa membedakan dengan memililah informasi beasiswa dengan melihat kualitas informasi yang didapat saat menemukan atau mendapatkan informasi beasiswa karena tidak ingin membuang waktu terlalu lama dalam proses pencarian serta ingin memastikan bahwa informasi beasiswa yang didapatkan sesuai dengan persyaratan serta relevan sebelum menelusuri dan mencari informasi melalui sumber asli yaitu website dan instagram resmi. Mahasiswa tidak akan menelusuri informasi lebih lanjut apabila informasi beasiswa yang didapat tidak sesuai. Selain itu pada penelitian ini kegiatan monitoring terjadi setelah kegiatan extracting karena mahasiswa akan memantau perkembangan informasi beasiswa apabila yakin untuk mendaftar yang sebelumnya mahasiswa akan menggali informasi melalui website dan instagram resmi penyelenggara beasiswa dan terdapat persyaratan dari pihak penyelenggara untuk memantau dengan cara mem-follow akun instagram resmi penyelenggra beasiswa apabila mendaftar beasiswa. Selain itu mahasiswa setelah melakukan kegiatan ending akan memantau kembali 
perkembangan informasi beasiswa. Hal ini dikarenakan mahasiswa ingin memantau terkait hasil pengumuman apabila terdapat pengunduran, perpanjangan, penambahan berkas dan informasi penting lainya.

\section{Hambatan yang Dihadapi Mahasiswa Fakultas Ilmu Budaya Universitas Diponegoro dalam Mencari Beasiswa melalui Media Online}

Perilaku pencarian informasi beasiswa setiap invidu berbeda dan tidak semua dapat berjalan dengan lancar. Terdapat hambatan atau kendala yang dialami individu pada saat melakukan kegiatan pencarian informasi. Mahasiswa Fakultas Ilmu Budaya Universitas Diponegoro menemukan berbagai hambatan atau kendala yang dialami saat melakukan kegiatan pencarian informasi beasiswa melalui media online. Hambatan yang dialami mahasiswa dapat menentukan dan mempengaruhi kegiatan perilaku pencarian informasi beasiswa dan dapat menjadi bahan evaluasi bagi para peneyedia informasi beasiswa agar dapat meningkatkan akses informasi beasiswa melalui sumber informasi media online yang digunakan.

Penelitian sebelumnya menyatakan bahwa kegiatan pencarian informasi tidak semua serta merta mulus dan sama bagi setiap individu. Proses ini menemui berbagai hambatan. Penelitian sebelumnya yang ditulis oleh Eviliyana, (2015), Wilson mengungkapkan terdapat hambatan yang dapat dialami individu dalam melakukan proses pencarian informasi diantaranya yaitu hambatan internal (hambatan individu atau personal) dan hambatan eksternal (hambatan lokasi dan karakteristik sumber informasi). Hal tersebut sejalan dengan penelitian yang dilakukan oleh peneliti yaitu Mahasiswa Fakultas Ilmu Budaya Universitas Diponegoro dalam mencari informasi beasiswa mengalami berberapa hambatan baik hambatan internal maupun hambatan eksternal. Hambatan yang dialami mahasiswa diantaranya kesulitan dalam menentukan kata kunci yang sesuai, terkendala akses internet dan hambatan yang berkaitan dengan karakteristik sumber informasi beasiswa. Hambatan yang dialami mahasiswa yang berkaitan dengan karakteristik sumber informasi beasiswa diantaranya seperti terlalu banyak informasi beasiswa yang dinilai kurang relevan dengan kebutuhan mahasiswa, informasi di website resmi tidak sesuai serta tidak terdapat narahubung, informasinya terbatas karena hanya memilik satu sumber informasi yang dapat diakses mahasiswa, informasi di website resmi tidak update dan informasi yang disampaikan tidak jelas, kurang lengkap dan terlambat dalam menyampaikan informasi penting. Selain itu mahasiswa juga mengalami hambatan terkait memastikan kredibilitas 
informasi beasiswa., hal ini dikarenakan dari sumber penyedia informasi beasiswa kurang memilah informasi beasiswa sebelum disebarkan ke publik.

\section{PENUTUP}

Simpulan

Berdasarkan hasil analisis data dalam penelitian mengenai perilaku pencarian informasi Mahasiswa Fakultas Ilmu Budaya Universitas Diponegoro dalam mencari beasiswa melalui media online, maka diperoleh simpulan bahwa perilaku pencarian informasi Mahasiswa Fakultas Ilmu Budaya Universitas Diponegoro dalam mencari informasi beasiswa terdiri dari beberapa tahapan kegiatan diantaranya kegiatan starting, differentiating, chaining, browsing, extracting, monitoring, verifying dan ending. Tahapan kegiatan perilaku pencarian informasi yang dilakukan mahasiswa terjadi karena adanya kebutuhan informasi beasiswa yang harus dipenuhi. Mahasiswa mencari informasi beasiswa dengan menggunakan berbagai sumber informasi media online diantaranya instagram, website, search engine google, facebook, twitter, line dan whatsapp yang berperan penting untuk memenuhi kebutuhan informasi dan untuk memperoleh informasi beasiswa.

Perilaku pencarian informasi Mahasiswa Fakultas Ilmu Budaya Universitas Diponegoro dalam mencari informasi beasiswa terdiri dari tahapan kegiatan diantaranya dimulai dari kegiatan starting, mahasiswa mencari informasi beasiswa dari sumber informasi yang pernah digunakan sebelumnya atau dengan bertanya kepada teman atau relasi. Differentiating, mahasiswa memilah informasi beasiswa yang sesuai persyaratan serta judul yang relevan dengan informasi yang dicari. Chaining, mahasiswa menelusur sumber informasi resmi penyelenggara beasiswa. Browsing, mahasiswa melakukan kegiatan pencarian dengan memindai website resmi dan instagram resmi. Extracting, mahasiswa menggali dan mengidentifikasi informasi beasiswa melalui website atau instagram resmi dengan menyimpan atau mencatat informasi penting. Monitoring, mahasiswa mem-follow akun instagram resmi untuk memantau perkembangan terbaru informasi beasiswa. Verifying, mahasiswa menilai dan memeriksa relevansi, keakuratan dan kredibilitas informasi beasiswa. Ending, mahasiswa menggabungkan, mendaftar mengumpulkan berkas persyaratan, berbagi dan memantau kembali perkembangan terbaru informasi beasiswa.

Mahasiswa mengalami beberapa hambatan dalam melakukan tahapan kegiatan pencarian informasi beasiswa diantaranya kesulitan dalam menentukan kata kunci, terkendala akses internet, terkendala terkait karakteristik sumber informasi beasiswa dan memastikan kredibilitas informasi beasiswa. Hambatan yang dialami mahasiswa dapat 
menjadi bahan evaluasi bagi para penyedia informasi beasiswa agar dapat meningkatkan akses informasi beasiswa melalui sumber informasi media online yang digunakan. Selain itu mahasiswa dalan mencari informasi beasiswa melalui media online harus lebih selektif dan cermat dalam menyeleksi informasi beasiswa dengan mengecek keakuratan dan kredibilitas informasi beasiswa sebelum mendaftar.

\section{DAFTAR PUSTAKA}

Amrullah, H. F., Ali, M. N. S., \& Sukimi, M. F. (2019). Information-Seeking Behavior of College Students on Religious Tolerance through Social Media. Islamiyyat, 41(2), 915. https://doi.org/10.17576/islamiyyat-2019-4001-02

Ariotejo, I. B., \& Ganggi, R. I. P. (2019). Persepsi Kolektif Sineroom Terhadap Perpustakaan Melalui Film Pendek The Library Book. Jurnal Ilmu Perpustakaan, 8(3), 82-93.

Braun, V., \& Clarke, V. (2006). Using thematic analysis in psychology. Qualitative Research in Psychology, 3, 77-101.

Devega, F., \& Irhandayaningsih, A. (2019). Perilaku Pencarian Informasi Fotografer Melalui Media Online oleh Komunitas Instanusantara Semarang. Jurnal Ilmu Perpustakaan, 8(4), 45-55.

Eviliyana, I. (2015). Perilaku Pencarian Informasi Mahasiswa Asing Peserta Darmasiswa Republik Indonesia Tahun Akademik 2014/2015 Universitas Diponegoro. Jurnal Ilmu Perpustakaan, 4(3).

Helaluddin dan Wijaya (2019). Analisis Data Kualitatif: Sebuah Tinjauan Teori \& Praktik. Sekolah Tinggi Theologia Jaffray.

Heriyanto. (2018). Thematic Analysis sebagai Metode Menganalisa Data untuk Penelitian Kualitatif. 2(3), 317-324.

Musabiq, S. A., \& Karimah, I. (2018). Gambaran Stress dan Dampaknya pada Mahasiwa. InSight, 20(2), 75-83.

Mutijah. (2016). Analisis keberhasilan belajar mahasiswa penerima beasiswa di iain purwokerto menggunakan regresi logistik. JPA, 17(2), 230-250.

Nihayati, \& Laksmi. (2020). Perilaku pencarian informasi pekerjaan oleh sarjana fresh graduate dengan analisis Model Wilson. Berkala Ilmu Perpustakaan Dan Informasi, 16(1), 55-67. https://doi.org/10.22146/bip.v16i1.171 
Rohmawati, N., Defiyanti, S., \& Mohamad Jajuli. (2015). Implementasi Algoritma K-Means Dalam Pengklasteran Mahasiswa Pelamar Beasiswa. Jurnal Ilmiah Teknologi Informasi Terapan, I(2), 62-68.

Semiawan, C. R. (2010). Metode penelitian kualitatif. Jakarta : Grasindo.

Sjach, B. (2009). Analisis perubahan pola bagi hasil rumah makan minang di Jakarta. Tesis. Tersedia dari Universitas Indonesia Library Database.

Suwanto, Sri Ati. 1997. Kebutuhan dan Perilaku Pencarian informasi Dosen Fakultas Kedokteran Undip dan Unissula Semarang. http://eprints.undip.ac.id/19618/1/sriatitesis.pdf. Tesis UI

Thindwa, T., Chawinga, W. D., \& Dube, G. (2019). Information-seeking behaviour of security studies students: A case study. SA Journal of Information Management, 21(1), 1-11. https://doi.org/10.4102/sajim.v21i1.1048

Utomo, P. (2011). Analisis Kontribusi Pemberian Beasiswa terhadap Peningkatan Prestasi Akademik Mahasiswa Fakultas Teknik Universitas Negeri Yogyakarta. Jurnal Pendidikan Teknologi Dan Kejuruan, 20(1), 1-15.

Weber, H., Becker, D., \& Hillmert, S. (2019). Information-seeking behaviour and academic success in higher education: Which search strategies matter for grade differences among university students and how does this relevance differ by field of study? Higher Education, 77(4), 657-678. https://doi.org/10.1007/s10734-018-0296-4

Yi, P. (2014). The impact of Korea' s National Scholarship program on college students ' academic achievement. KEDI Journal of Educational Policy, 11(2), 285-307.

Yulma, N. L., \& Herianingrum, S. (2016). Peran Pemberdayaan Wakaf Tunai (Studi Kasus Pada BMT Amanah Ummah Surabaya). Jurnal Ekonomi Syariah Teori Dan Terapan, 3(11), 856 